\title{
The Potential of Contingent Valuation for Planning Practice. The Example of Dortmund Westpark
}

\author{
Jost Wilker ${ }^{1}$ Dietwald Gruehn ${ }^{2}$
}

Received: 19 January 2016 / Accepted: 15 December 2016 / Published online: 10 January 2017

(C) Springer-Verlag Berlin Heidelberg 2017

\begin{abstract}
This paper highlights the practical opportunities that contingent valuation can deliver to improve park management. Although green infrastructure, such as urban parks, provides huge benefits to society, investments require a strong economic justification and have to be based on societal needs and preferences. Accordingly, this paper investigates, by means of a survey of willingness to pay and willingness to work, how users value possible improvements to the management of Dortmund Westpark, and which determinants influence their decisions. In line with the scientific discussion of integrating economic valuation in decision making, we introduce a simple approach to applying valuation results to planning. Total willingness to pay and willingness to work are set in proportion to the real-time costs of suggested proposals. To make the findings useful
\end{abstract}

This manuscript includes findings from Jost Wilker's diploma thesis entitled "GrünAnlage - Was ist uns Stadtgrün wert? Ökonomische Bewertung des Westparks in Dortmund", which was submitted to the School of Spatial Planning at TU Dortmund University in 2010.

Substantial parts of this recent contribution have been developed at the Research Institute for Regional and Urban Development $\mathrm{gGmbH}$ (ILS) in Dortmund.

$\triangle$ Jost Wilker

jost.wilker@tu-dortmund.de

Prof. Dr. Dietwald Gruehn

dietwald.gruehn@tu-dortmund.de

1 Ministerium für Klimaschutz, Umwelt, Landwirtschaft, Natur- und Verbraucherschutz des Landes Nordrhein-Westfalen, Schwannstraße 3, 40476 Düsseldorf, Germany

2 Lehrstuhl Landschaftsökologie und Landschaftsplanung, Technische Universität Dortmund, August-Schmidt-Straße 10, 44221 Dortmund, Germany for park management, these proposals consider the weighting of users' preferences. Total hypothetical working hours are also integrated into the approach by proposing where they could be used most effectively. Our study reveals the high social values people attach to park improvements and demonstrates the potential benefits of contingent valuation study results for decision making.

Keywords Green infrastructure planning - City parks . Contingent valuation $\cdot$ Park management $\cdot$ Decision making

\section{Das Potenzial der Kontingenten Bewertung für die Planungspraxis. Das Beispiel des Dortmunder Westparks}

Zusammenfassung Diese Studie untersucht die praktischen Möglichkeiten, die die Kontingente Bewertungsmethode dem Management von Grünflächen bieten kann. Obwohl grüne Infrastrukturen, wie Parks, eine Vielzahl von Leistungen für die Gesellschaft erbringen, sind Investitionen in sie zunehmend einem erhöhten gesellschaftlichen Bedürfnis- und ökonomischen Rechtfertigungsdruck ausgesetzt. Dementsprechend analysiert dieser Beitrag mittels einer Zahlungs- und Arbeitsbereitschaftsbefragung, wie Parkbesucher des Dortmunder Westparks bestimmte Verbesserungsmaßnahmen bewerten und was mögliche Einflussfaktoren ihrer Entscheidungen sind. Vor dem Hintergrund der anhaltenden wissenschaftlichen Diskussion zur Integration ökonomischer Bewertungsergebnisse in die planerische Entscheidungsfindung, stellen wir einen Ansatz zum Transfer der erlangten Informationen für das Grünflächenmanagement vor. Dazu werden die Werte der Zahlungs- und Arbeitsbereitschaft ins Verhältnis zu den Echtzeitwerten 
der vorgeschlagenen Maßnahmen und der Präferenzen der Parkbesucher gestellt. Die hypothetisch zu leistenden Arbeitsstunden finden außerdem Berücksichtigung, indem effektive Einsatzbereiche aufgezeigt werden. Auf diese Weise wird die hohe gesellschaftliche Wertschätzung, die Menschen Verbesserungen der grünen Infrastruktur zukommen lassen, dargestellt, und es wird diskutiert, wie sie mithilfe der Kontingenten Bewertungsmethode Eingang in die planerische Entscheidungsfindung erlangen kann.

Schlüsselwörter Grüne Infrastruktur •

Stadtparks - Kontingente Bewertungsmethode .

Grünflächenmanagement · Entscheidungsfindung

\section{Introduction}

There is no doubt that urban parks deliver many important benefits to people, nature and the local economy (Gälzer 2001; McConnell/Walls 2005). Parks are a type of urban green infrastructure (Amundsen/Allen/Hoellen 2009) and provide ecosystem services that support societal wellbeing and quality of life, including recreation, improved air quality and nature-related aesthetics (Chiesura 2004; James/Tzoulas/Adams et al. 2009; Europäische Kommission 2013).

\subsection{Background}

Despite the established benefits of green infrastructure, local authorities increasingly have to cope with limited financial resources. Therefore, efficient investment in green infrastructure, such as city parks, is critical (Grunert 2001; Wilker/Rusche 2014). Financial arguments often outweigh social ones in deliberations over green infrastructure. Public parks are prototypical public goods with a high degree of non-excludability and non-rivalry (Carson/Flores/Meade 2001; Klaphake 2003), i.e. people cannot be excluded from using a park and do not compete in consuming it (except for space allocation). Due to this lack of scarcity and the character of public goods, there are no market prices for city parks (Arrow/Solow/Portney et al. 1993). This results in an essential weakness for green infrastructure planning in relation to other fields of planning, such as transportation, services and industry, in which investments generate direct economic and fiscal benefits in the form of tax revenue and jobs (Schröder 2000). Moreover, because politicians and decision makers often see green infrastructure as cost intensive, budgets for park management units are under increasing pressure (Milchert 2005). Therefore, to influence the opinions of decision makers and the public on urban green infrastructure, it is essential to highlight the social, ecological and economic importance of city parks and to highlight the relevance of user-oriented park management (Klaphake/Meyerhoff 2003; Costa 2007). Economic valuation techniques, especially stated preference methods, may encourage new ways of thinking in planning because they can be used to assess use and non-use values of goods and services, even before an actual investment takes place (Bateman/Harwood/Mace et al. 2013).

\subsection{Research question}

Accordingly, this paper examines the contingent valuation method (CVM) as an approach to supporting and financing green infrastructure planning and the management of city parks. By providing important information on public preferences and valuation of improvement measures, the contingent valuation method can support efficient local planning policy. Users of the centrally located Westpark in Dortmund, Germany, were surveyed on their preferences for potential improvements in park management and their hypothetical willingness to pay (WTP) and willingness to work (WTW) for the improvements. This paper discusses the practical opportunities for park management arising from the survey results. It provides specific suggestions that could be implemented using a hypothetical budget informed by park users' willingness to pay and willingness to work, which reflect the social value of city parks. In the case of Westpark, willingness to pay and willingness to work values for potential improvements may help to prioritize future policy and management actions, as surveying can be an important instrument for involving stakeholders in local spatial planning (Gruehn 2013).

Many other studies have concentrated on the contingent valuation method or applied it to city parks around the world, revealing the importance of discussing the value of parks. Nevertheless, most of these studies lack any discussion of the practical relevance or applied results of contingent valuation (CV) analyses for green infrastructure planning and park management (Elsasser/ Meyerhoff/Montagné et al. 2009; Wilker/Rusche 2014). Christie (1999), Klaphake (2003) and Jilkova, Holländer, Kochmann et al. (2010) note the need to recognize the practical importance of contingent valuation for green infrastructure planning and decision making. "The Economics of Ecosystems and Biodiversity" (TEEB) studies have also demonstrated this with regard to ecosystem services and biodiversity (Slootweg/van Beukering 2008; TEEB 2010). Although this sheds light on the underlying problem, studies rarely investigate specific proposals on the basis of people's total willingness to pay and willingness to work. Thus, there is an opportunity to "translate" contingent valuation studies of green infrastructure projects so that they can be used more efficiently by practitioners 
and decision makers (James/Tzoulas/Adams et al. 2009; Bateman/Harwood/Mace et al. 2013).

In the following section, we introduce the contingent valuation method and its application by reviewing contingent valuation studies focusing on city parks and their main implications for park management. We also discuss briefly the strengths and weaknesses of the method. Then, the case study of Dortmund Westpark is explained. Next, the application of the contingent valuation method to Westpark is outlined. In the results section, we present users' preferences and their willingness to pay and willingness to work for improvement categories, their favoured proposals, and the determinants of their choices. Based on the results, implications and recommendations for the management of Westpark and the future use of contingent valuation in green infrastructure planning are discussed. Finally, we draw a conclusion.

\section{The use of contingent valuation in park management}

The contingent valuation method is a survey-based approach to the economic valuation of public goods (Carson/ Flores/Meade 2001), which means it is able to capture use and non-use values and is applicable ex ante and ex post to almost all public goods (Pearce/Atkinson/Mourato 2006). Today, the contingent valuation method is by far the most popular stated preference approach for valuing green infrastructure assets and the benefits they are able to provide through healthy ecosystems (Pearce/Atkinson/ Mourato 2006; Freeman III./Herriges/Kling 2014; Wilker/ Rusche/Benning et al. 2016). A questionnaire is used to create a hypothetical payment scenario. The questionnaire results reveal respondents' willingness to accept (WTA), willingness to pay, and/or willingness to work for hypothetical changes in the provision of a green infrastructure element such as a park (Klaphake/Meyerhoff 2003; TEEB 2010). While willingness to accept in this context could be the minimum amount that residents would accept as compensation for losing a section of a park to the development of houses, willingness to pay could be the maximum amount they are willing to spend to financially support improvements in the park, and willingness to work could be the amount of physical work they would carry out to cut the grass themselves.

After describing the park itself and the institutional context, a typical contingent valuation questionnaire is divided into three parts (see Pearce/Atkinson/Mourato 2006; Stewart/Kahn 2009; Freeman III./Herriges/Kling 2014; Wilker/ Rusche 2014). Firstly, use frequency, usage and users' attitudes are surveyed by asking respondents to give information on their use frequency and reasons for using the good.
In addition, users' opinions on the features and characteristics of the park in question are surveyed. Secondly, the willingness to accept, willingness to pay and/or willingness to work scenario is presented. On the basis of respondents' attitudes and ideas, people are directly asked to express their willingness to accept, willingness to pay and/or willingness to work for the hypothetical changes to the park. To minimize any biases, the respondents are instructed to answer the questions as realistically as possible. In this way, the amount that respondents are willing to accept, willing to pay and/or willing to work for a certain change can be identified, thus indicating the attractiveness of the change (Pearce/Atkinson/Mourato 2006). In the case of willingness to accept and willingness to pay, the chosen payment vehicle, i.e. the way a certain monetary amount is collected, can for example involve compensation or financial incentives, or a hypothetical fund, tax increases or entrance fees. Thirdly, socio-economic characteristics such as origin, age, gender, education, job and salary are recorded as they can be important determinants for respondents' answers.

\subsection{Case studies from the literature}

Numerous contingent valuation case studies of city parks have been published. We only refer to studies that provide valuable information about the relevance of contingent valuation results for the management of city parks and try to link their results to decision making. Monetary values from the studies were converted into rough Euro values for better comparison. Ahmed and Gotoh (2007) applied contingent valuation to investigate households' willingness to pay for the preservation of all public city parks in Nagasaki, Japan. The aim of this study was to develop policy recommendations. The survey of 1,000 households, with a $20 \%$ response rate, revealed an extrapolated total willingness to pay of around EUR 7 million (EUR 40 per household) (Ahmed/ Gotoh 2007: 53). A voluntary contribution to a hypothetical public park protection fund was established as the payment instrument. In addition to deriving recommendations for the improvement and preservation of city parks in Nagasaki, the authors note that the contingent valuation method should be considered as a tool for understanding residents' preferences and including them in decision-making (Ahmed/ Gotoh 2007: 59).

A contingent valuation study in Valencia, Spain, focused on the non-market benefits of a new urban park in the city centre, which was deficient in green space (Del Saz Salazar/ Menendez 2007). The authors interviewed 900 randomly selected inhabitants, who expressed a weighted mean willingness to pay of EUR 54 and a total estimated benefit of EUR 50,000 (Del Saz Salazar/Menendez 2007: 303). A discrete choice model with an elicitation method was used for the payment scenario and a special tax was chosen as the 
payment vehicle. The results show that respondents' willingness to pay decreases as the amount of the potential tax increases. Del Saz Salazar/Menendez (2007: 304) argue that a fair local tax policy should consider that households living closer to the park gain greater benefits than those living farther away. Further, they stress that the estimation of nonmarket benefits is a key element of urban planning and decision making, as contingent valuation is a flexible tool that can be very helpful for public authorities and private citizen groups (Del Saz Salazar/Menendez 2007: 304).

Willis (2003) investigated the feasibility of implementing an entrance fee to the Real Bosco di Capodimonte in Naples, Italy. The study examines the effects of different entry fees on the number of visitors and increases in revenue, which could be used to cover high maintenance costs. Willis (2003: $9 \mathrm{ff}$.) found support for, depending on the chosen approach, an entrance fee of EUR 2.60 per visit, or between EUR 1.96 for economically inactive (unemployed) visitors and EUR 6.63 for economically active (employed) visitors. The total potential revenue ranges from EUR 240,000 (unitary price system) up to EUR 367,000 (price discrimination). However, although both revenue amounts are greater than the operating costs of the entry price scheme (EUR $115,000)$, they would only cover a small part of the annual maintenance and expenditure costs for the Bosco (around EUR 520,000). Willis (2003: $13 \mathrm{f}$.) concluded that the introduction of an admission fee would result in fewer park visits and that the park's total use value to users is maximized and socially optimal when the entry price is zero. Nevertheless, the government was looking for ways to generate revenue from park visits (Willis 2003).

In Germany, two similar case studies focused on the capital of Berlin and its various city parks. Klaphake and Meyerhoff (2003) investigated the value of improvement measures in Volkspark Hasenheide. They interviewed more than 300 users about their preference for intensive horticultural maintenance, better waste disposal, or both. Their contingent valuation approach used a dichotomous nominal question to survey respondents' willingness to pay and a voluntary annual ticket as the payment vehicle. $35 \%$ of the interviewees were willing to pay, generating an average of EUR 10.50 and total revenue of EUR 0.99 to 1.32 million. (Klaphake/Meyerhoff 2003: 107).

Another contingent valuation study was conducted in Berlin by Matz (2006) at Görlitzer Park. Matz adopted the basic methodological approach of Klaphake and Meyerhoff (2003) and offered the hypothetical provision of additional cleaning staff (to cope with dog waste and other litter) as well as increased horticultural maintenance (such as the upkeep of playgrounds and the planting of vegetation along the lake). The payment vehicle was also a voluntary annual ticket assisted by a payment card. In contrast to Klaphake and Meyerhoff (2003), Matz (2006) asked respondents who were unwilling to pay about their willingness to work to implement favoured proposals. Approximately $40 \%$ of the users stated a willingness to pay or a willingness to work (Matz 2006: 63). Further, Matz (2006: $68 \mathrm{f}$.) revealed an average adjusted willingness to pay of EUR 10.31 and an annual willingness to work of 15 hours, which would generate a total of EUR 150,000 and 150,000 working hours provided by park users per year. The study also found that most respondents were interested in a combination of both improvement categories.

The discussion of case studies underlines the valuable information contingent valuation results can provide to park management by revealing users' preferences, their appreciation and willingness to pay and/or willingness to work for different planning options and possible policy recommendations. Ahmed and Gotoh (2007) and Del Saz Salazar and Menendez (2007) clearly stress the potential role of contingent valuation as a planning tool.

\subsection{Discussing Contingent Valuation}

Like all economic valuation methods, contingent valuation has empirical and methodological weaknesses that are passionately discussed in the literature (Carson/Flores/Meade 2001; Hausman 2012; Haab/Interis/Petrolia et al. 2013). In summary, there are three main constraints on contingent valuation that are problematic (Hausman 2012). The first constraint is a hypothetical bias, which cannot easily be dispelled, and occurs due to the hypothetical situation created within a contingent valuation survey. People are rarely asked about their willingness to pay or willingness to work and might, for various reasons (see Hausman 2012), not state a contribution they would make in real life. Therefore, results may be upward-biased (Johnston 2006). Nevertheless, Haab, Interis, Petrolia et al. (2013) argue that hypothetical biases can be limited if the good to be valued is clearly explained to the respondents and the respondents believe that their answers matter. Furthermore, adjusting the scenario can also help to decrease hypothetical biases (Haab/Interis/Petrolia et al. 2013: 593). Second, differences between willingness to pay and willingness to accept are a problem; according to economic theory, they should reveal roughly the same values (Hausman 2012: $46 \mathrm{f}$.). However, a gap between willingness to pay and willingness to accept impedes the use of contingent valuation in policy and decision making and suggests that results are not reliable. Again, Haab, Interis, Petrolia et al. (2013) counter Hausman by referring to Knetsch (2010) and explain the WTPWTA divergence by the fact that people value losses more than gains (Knetsch 2010: 180). Third, contingent valuation can be subject to scope and embedding effects (Hausman 2012). This means that a good can be valued individually or as part of a project and contingent valuation operators 
Fig. 1 Location of Westpark

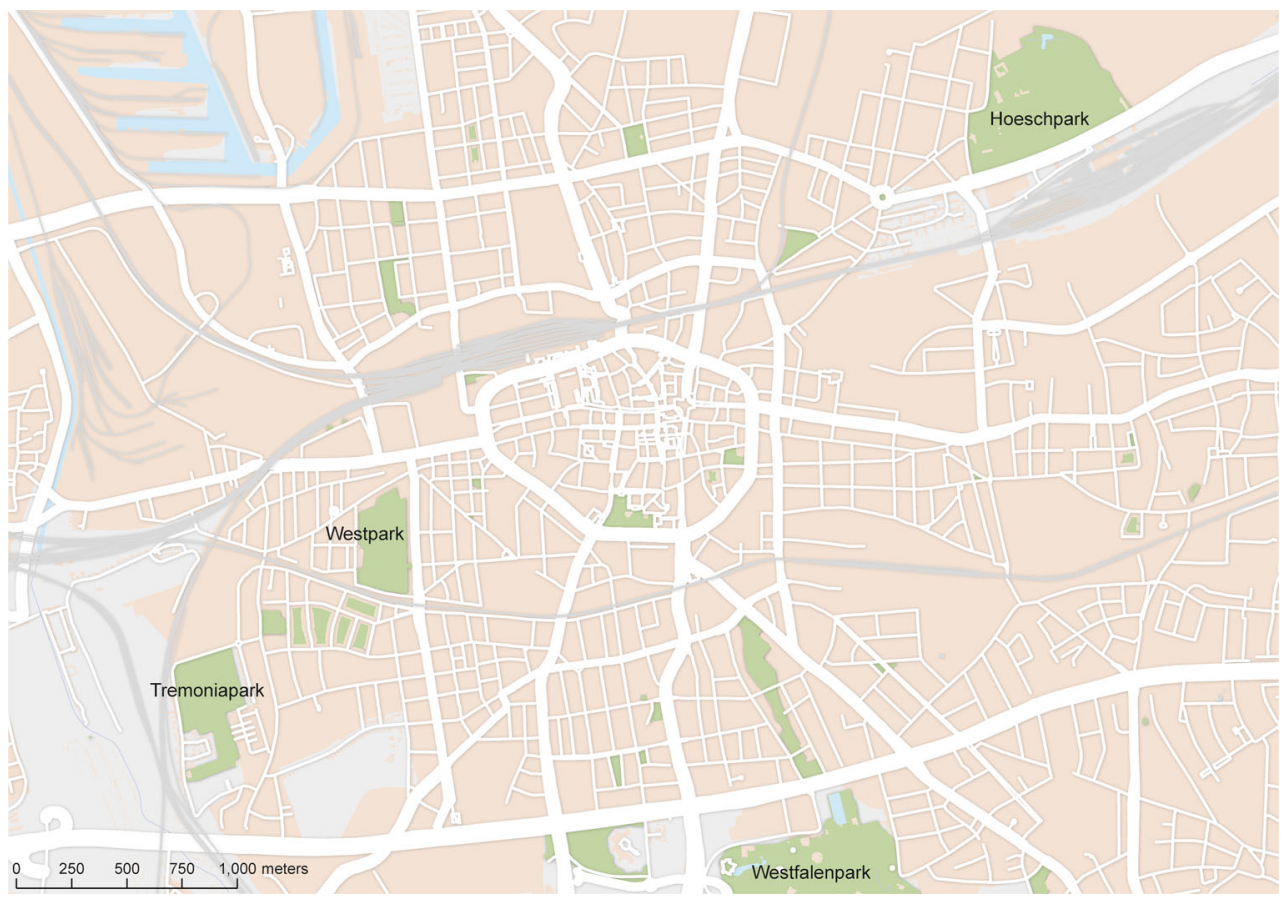

cannot be sure what respondents actually value. A scope test or an adding up test can provide additional information to help mitigate this problem (Haab/Interis/Petrolia et al. 2013: 593). Altogether, conducting contingent valuation is complex and the results are often contested due to biases, which make it difficult to control all variables.

However, despite these weaknesses of contingent valuation, we agree with Carson (2012) and Haab, Interis, Petrolia et al. (2013) that the evidence provided by contingent valuation is better than no evidence at all, and share the notion from the literature on contingent valuation studies that this method offers many opportunities and insights for practical planning. Thus, contingent valuation should be used more frequently to inform both policy making and benefitcost analysis. Against the background of the studies presented above, it becomes obvious that contingent valuation is a useful tool for collecting users' preferences and revealing them in a WTP/WTW scenario of park management. Most studies provide WTP/WTW values for park improvements and reveal some of respondents' determinants based on contingent valuation. However, no study has yet established a park's total value in relation to the real time costs of park management measures and used this information to make policy recommendations. This research gives the social value of park improvements a more practical dimension and suggests investments, for policy consideration, according to users' needs.

\section{Westpark in Dortmund}

Westpark is a large (nine-hectare) public park located on a former cemetery in the western part of the city centre in the city of Dortmund (see Figure 1), which is situated in the eastern part of the Ruhr area in Germany (see Stadt Dortmund 2006). It is one of the few public green spaces in this densely populated and, in parts, socially deprived area (see Neumeyer/Kieslich/Liesen 2004). It provides a wide range of leisure and recreation opportunities primarily for local users. Two thirds of its area is open lawn with trees, which is mostly used for sunbathing and barbecuing. Trees, groves of shrubs and flowerbeds are the dominant landscaping elements. For recreation, the park offers two playgrounds, boules, benches, a jogging track, two cafes and a dense path network. However, due to the varied and intense use, problems such as antisocial behaviour and vandalism occur in Westpark.

The following information were derived from a number of observations obtained during site visits and expert interviews with representatives from the park's management, the local regulation agency, the police and the neighbourhood's management. Further, we attended several meetings of the Westpark working group (see Wilker 2010). The working group was established to deal with problems in Westpark and is open to representatives from the affected local stakeholder groups (municipal park management, district council, police, retailers, restaurant operators, and citizens).

Westpark is one of only a few public parks in Dortmund where barbecuing is allowed and this makes it very popular. However, problems associated with barbecuing include 
Fig. 2 Payment card. The circular text in the middle says: "Of my household's income I pay a maximum annual amount of ... $€$ ". The payment card displays Euro values from 0 to "above 300" and includes also an "I don't know" option

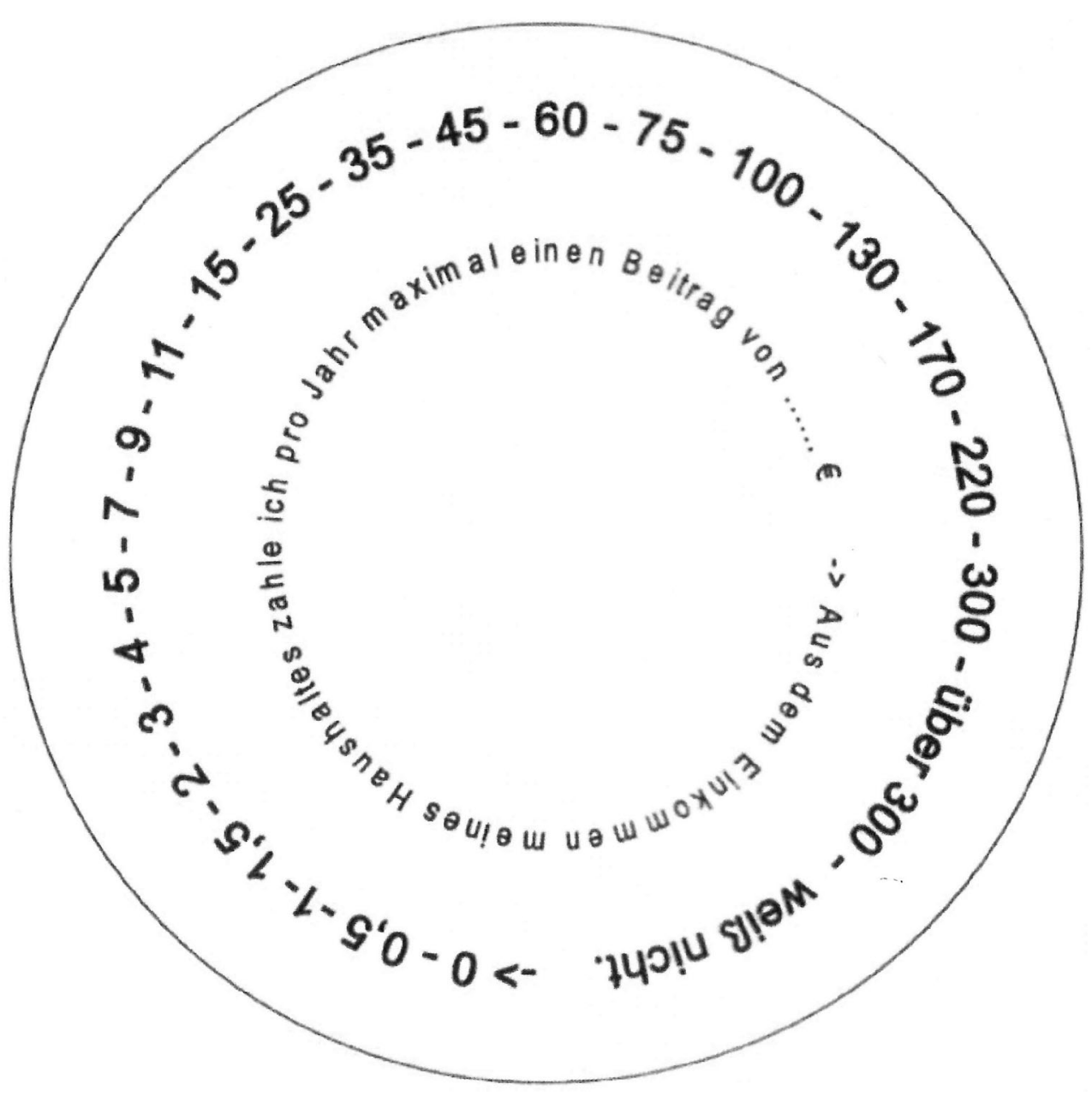

frequent dumping of ashes, bottle caps, and cigarette butts on the lawn. Another issue in Westpark is crime, especially vandalism and drug dealing. The playgrounds and lights are in poor condition due to vandalism. Benches are less frequently a target of vandalism, but there seem to be too few for the high demand on sunny days. There is a fee for use of the public toilet and therefore it is rarely used. Public urination into shrubs is a daily occurrence.

The park management of the City of Dortmund, in cooperation with different local stakeholders, tries to cope with the aforementioned issues with measures such as police presence, shrub- and tree-pruning for better visibility, repair services and regular waste collection. Nevertheless, there remains a high need for additional amendments and maintenance in Westpark. This is problematic because its maintenance costs are about EUR 130,000 per year and there is no extra funding for improvements to the facilities and services (Wilker 2010: 50). Against the rising financial constraints on public administration in Germany, especially in the City of Dortmund, these limited resources create a challenge for future park management and require efficient use.

\section{Methods}

To guarantee reliable results, our application of the contingent valuation method in the Westpark user survey adhered to the standard guidelines in the literature (Mitchell/ Carson 1989; Arrow/Solow/Portney et al. 1993; Bateman/ Landford/Willis et al. 1993; Venkatachalam 2004; Pearce/ Atkinson/Mourato 2006). To minimize hypothetical biases, the complex circumstances of the hypothetical willingness to pay or willingness to work scenarios were explained in detail personally to interviewees on-site. A payment card was given to users to limit the number of protest answers and cancelled interviews for the open-ended WTP question (Gronemann/Hampicke 1997) (see Figure 2).

Source: Matz (2006: Anhang C)

The possible improvements were clearly described to address scope and embedding effects. Furthermore, the questionnaire was pretested with Westpark visitors to review the suitability of different payment vehicles (entrance fee vs voluntary fund payment/willingness to work). Willingness to accept was not included in the survey as the park improvements were understood as gains, not losses, to the 
Table 1 Improvement areas and proposals

\begin{tabular}{|c|c|c|c|}
\hline $\begin{array}{l}\text { Improvement } \\
\text { area }\end{array}$ & Proposals & & \\
\hline Security & More security staff & More lights & $\begin{array}{l}\text { Closed-circuit } \\
\text { television }\end{array}$ \\
\hline Cleanliness & More waste bins & $\begin{array}{l}\text { More clean- } \\
\text { ing staff }\end{array}$ & \\
\hline $\begin{array}{l}\text { Horticultural } \\
\text { mainte- } \\
\text { nance }\end{array}$ & $\begin{array}{l}\text { More tree- and } \\
\text { shrub-pruning }\end{array}$ & $\begin{array}{l}\text { Add exotic } \\
\text { plants }\end{array}$ & \\
\hline $\begin{array}{l}\text { Design and } \\
\text { furniture }\end{array}$ & More benches & More toilets & $\begin{array}{l}\text { Better/new } \\
\text { playgrounds }\end{array}$ \\
\hline
\end{tabular}

park's current status and therefore willingness to accept was not appropriate (Knetsch 2010).

\subsection{The Pretest}

In a pretesting phase, approximately 30 Westpark users were surveyed. Mainly, the pilot was run to optimize the valuation part of the questionnaire. With this regard, the utility of asking willingness to pay questions for the current and the possible future status of the park were explored. Further, different versions of the questionnaire were used to test both a hypothetical fund and entrance fees as payment schemes. Reasons for visiting the park and suggestions about specific improvement proposals in response to open questions from the pilot were used to create categories in the final questionnaire. As another response to the pilot we decided to include voluntary willingness to pay and willingness to work in the valuation part of the questionnaire as some respondents rejected an entrance fee as payment vehicle and refused payment. For people who might refuse to pay into a hypothetical fund, we included a 'no-answer' option and offered the possibility to do physical work to improve the park. Willingness to work was also integrated into the survey in consideration of the social context of the district where Westpark is located, which is characterized by relatively high unemployment rates and a diversity of ethnic groups. The willingness to work option allows those respondents who do not want to or cannot afford to pay into the hypothetical fund to nevertheless contribute to the enhancement of the park. In this way, the inclusion of the WTW option addresses biases as well as giving users the hypothetical opportunity to actively be part of the park management process and campaign for their interests. These various steps were taken to minimize typical problems with strategic and hypothetical biases and scope and embedding effects common in contingent valuation surveys.

\subsection{The Survey}

The aim of the user survey in Dortmund Westpark was to estimate visitors' preferences for improvement measures related to park management, the extent to which they valued such improvements and to understand their decisions. This information is especially relevant with regard to sustainable park management, keeping in mind the multiple functions, high popularity, and diverse problems of the park plus the limited financial resources the park management has available to manage and invest in the park.

Four areas for improvement and specific proposals related to current problems in Westpark were identified by means of expert interviews, meetings and the pilot: security, cleanliness, horticultural maintenance, design and furniture. Users were asked to state their preference for up to two improvement areas. Subsequently, respondents could specify their interest in specific park improvements by choosing from proposals related to the four improvement areas (see Table 1).

After expressing their detailed preferences for proposed park enhancements, respondents were surveyed about whether they would be willing to pay to support the selected proposal(s) in their preferred improvement area(s). If users were willing to pay, they were asked in an open question about the annual amount they would voluntarily contribute into a hypothetical, earmarked fund. The payment card, as a commonly employed tool in these cases, was used to facilitate respondents' decision making regarding hypothetical payments (Meyerhoff 2004; Matz 2006; Jilkova/Holländer/Kochmann et al. 2010; Wilker/Rusche 2014) (see Figure 2). Respondents not willing to pay were offered the option of implementing their preferred proposals and supporting the park management by contributing physical work. When stating willingness to work, users were asked in an open question about the monthly number of hours they would be willing to work from April to September.

In addition to the valuation section and the hypothetical scenario, the questionnaire contained typical contingent valuation survey components dealing with frequency and characteristics of respondents' park use as well as personal information (Pearce/Atkinson/Mourato 2006; Whitehead 2006; Freeman III./Herriges/Kling 2014).

\section{Results}

In total, 160 adult respondents were interviewed on weekdays and weekends. 12 respondents aborted the interview for various reasons, and therefore 148 valid questionnaires were used for analysis of the results. Quite equal amounts of women (78) and men (70) took part in the survey, which 


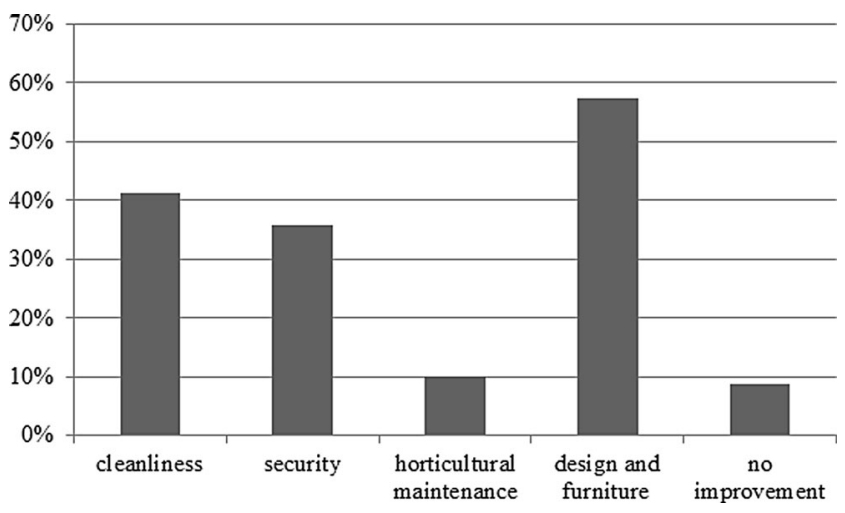

Fig. 3 Preferences for improvement areas $(\mathrm{N}=148)$

is in line with the overall distribution of women and men in the surrounding district and in the city of Dortmund, with slightly more women than men. The participants of the survey were rather young, as nearly three quarters were below 50 years of age; similarly distributed among women and men. About two thirds of the interviewees live in the postcode area where Westpark is located. Hardly any respondents' home is situated outside of Dortmund, which shows the highly local, city-wide importance of Westpark. Despite Westpark's local popularity, most respondents (76.4\%) also regularly visit other parks in Dortmund. Among these, Westfalenpark and Rombergpark, both with a certain botanical value and located in the south of Dortmund, are the favourites. A strong majority of the respondents $(\mathrm{N}=135)$ stated their preference for at least one of the four improvement areas. Interviewees most frequently chose enhancements related to design and furniture. The second and third highest most favoured categories were cleanliness and security, while horticultural maintenance was least popular (see Figure 3).

According to these results, most proposals mentioned by the respondents were related to the design and furniture improvement category. New and reconstructed playgrounds, more benches and more toilets were specifically requested. Regarding cleanliness, more waste bins and better waste disposal were seen as desirable. To increase security, more security staff and more lights were important to users.

\subsection{Willingness to pay and willingness to work}

Respondents who identified a need for improvements in Westpark were asked if they would be willing to pay any amount, on a voluntary basis, into an earmarked fund to support their desired improvements and proposals. Of the 135 users, $40 \%$ expressed a general willingness to pay, while the majority refused any financial contribution. Of the latter, $32.5 \%$ was willing to work, which means that $54 \%$ of all respondents were willing to support improvements. The respondents willing to pay were surveyed re- garding the annual amount they would be willing to donate to the fund for improvement measures in Westpark. The average amount among those respondents was nearly EUR 25 annually, while the median was EUR 20 per year. The absolute willingness to pay averaged among all survey respondents was EUR 9.09. Comparable studies applying contingent valuation to parks in Germany (see Klaphake/ Meyerhoff 2003: 107; Matz 2006: 68) reveal quite similar estimates. The average willingness to work among the respondents willing to work is 9.21 hours per month in the seasonal period from April through September. Considering all respondents, the value is 1.62 hours per month, which is lower than in a comparable study where this value was 2.48 hours (Matz 2006: 65). The average proportional and absolute willingness to pay and willingness to work values for the four improvement areas are shown in Figure 4.

Respondents showed the highest interest in park design and furniture enhancements: nearly $65 \%$ of the respondents willing to pay and $56 \%$ of the respondents willing to work wished for improvements in park design and furniture. Moreover, of all improvement categories, respondents assigned the highest average willingness to pay and willingness to work values to park design and furniture. Cleanliness was also well supported, as more than half of the interviewees would pay around EUR 20 per year for a cleaner park (to be achieved by the provision of more waste bins and better waste disposal services). People willing to pay were less in favour of security and horticultural amendments, although the average willingness to pay for the latter was also EUR 20. The willingness to work values differ only marginally among the categories; only physical work for better cleanliness was less popular than the other improvement categories. These results clearly address the need for action in future park management in Westpark, which should mainly focus on the provision of attractive playgrounds, more benches and a cleaner park through the installation of more waste bins and the establishment of a better waste disposal service.

\subsection{Determinants of willingness to pay and willingness to work}

To investigate why interviewees stated a willingness to pay or a willingness to work and the amounts they reported, cross-tabulations were produced for 36 independent variables. The cross-tabulations helped to identify differences in the percentage ratios between the dependent variables and the independent variables in relation to their average ratios. Next, those variables showing considerable deviations were set in relation to willingness to pay, willingness to work, and their reported amounts by means of Spearman's rank correlation coefficient. For this purpose, willingness to pay and willingness to work values were both transferred 
Fig. 4 Willingness to Pay $(\mathrm{N}=54)$ and Willingness to Work $(\mathrm{N}=27)$ for improvement areas

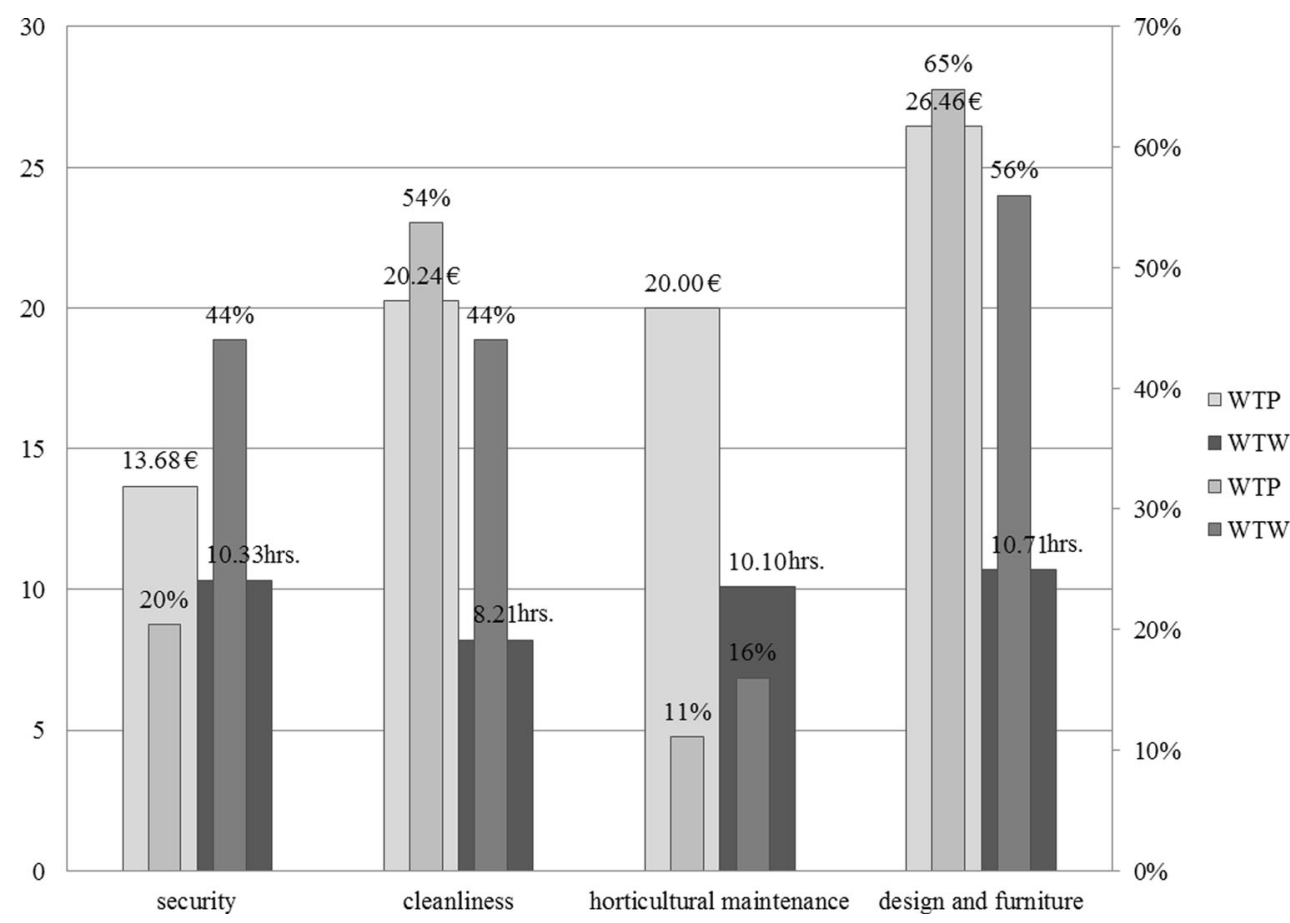

into intervals to make them suitable for the application of Spearman's rank correlation coefficient (Bühl 2010: 388). It displays the statistical dependence and relationship between two variables and ranges between +1 and -1 , while both values are considered to express strong positive or negative correlations between the two variables. To produce reliable conclusions, only independent variables that are at least significant on a five percent level are considered. In this way, the rationales of respondents who are either willing to pay or willing to work, as well as the amounts they are willing to pay or willing to work, can be estimated, which may produce helpful information for park management.

Out of the 36 independent variables, seven provide significant correlation values at the 0.01 or 0.05 levels (see Table 2). Tables 3 and 4 depict the variables with significant correlations in relation to the general willingness to pay (WTPgen), the absolute willingness to pay (WTPabs) and the general willingness to work (WTWgen). For the absolute willingness to work (WTWabs), no clear relation with any independent variable is observable and none is significant, which may be due to the low number of respondents in each group (see Table 2).

One characteristic of those respondents who are willing to pay is that they stay longer than average in Westpark for a single visit. Particularly, the share of respondents visiting the park for more than two hours ( $>2-3$ h., $>3-4 \mathrm{~h}$. and $>4$ h) is up to seven percentage points higher than the average (see Tables 2 and 3). The correlation between respondents' length of stay in the park and their willingness to pay is highly significant at the 0.01 level, while the coefficient of 0.277 describes a low correlation (see Table 4). A long stay may increase the probability that users are willing to pay because people who like to visit Westpark and spend time enjoying its various recreation and leisure opportunities will attach a certain value to these opportunities. This seems logical, as they use the park rather than merely commuting through it and are more likely to barbeque in the park than others. The difference between interviewees who are willing to pay and are also visiting the park for barbequing and those respondents who are not willing to pay is approximately 15 percentage points; the difference for the reason of transit is about the same (see Table 3). These correlations are both very low (below $+/-0.2$ ), although they are significant. People who only cross the park to reach their destinations are willing to pay significantly less than others, especially when compared to those users whose length of stay is above average. No one who only crosses the park would be willing to pay more than EUR 5. These respondents do not use the park for its amenities, unlike those respondents who like to use the park for its functions. Interviewees who are rather willing to pay and tend to do so above average do not significantly support improvements in security. They may feel that additional security is unnecessary because they already feel considerably safer in the park than the average respondent. Accordingly, this also means that respondents interested in better security are less willing to pay. This may hint at a type of protest bias, as respondents expect a certain level of security in public green spaces such as Westpark and believe local park management should provide that security without any additional funding. However, with an enhanced feeling of personal safety, willingness to pay for improvements other than se- 
Table 2 Definitions and proportions of dependent and independent variables

\begin{tabular}{|c|c|c|c|c|c|c|c|}
\hline \multirow{8}{*}{$\begin{array}{l}\text { Dependent } \\
\text { variables }\end{array}$} & \multirow[t]{2}{*}{ WTPgen $(\mathrm{N}=135)$} & no & yes & & & & \\
\hline & & $60 \%$ & $40 \%$ & & & & \\
\hline & \multirow[t]{2}{*}{ WTPabs (N=135) } & $0 €$ & $>0-5 €$ & $>5-15 €$ & $>15-30 €$ & $>30 €$ & \\
\hline & & $60.0 \%$ & $8.9 \%$ & $10.4 \%$ & $12.6 \%$ & $8.1 \%$ & \\
\hline & \multirow[t]{2}{*}{ WTWgen $(\mathrm{N}=81)$} & no & yes & & & & \\
\hline & & $67.9 \%$ & $32.1 \%$ & & & & \\
\hline & \multirow[t]{2}{*}{ WTWabs (N=81) } & $0 \mathrm{~h}$. & $>0-5 \mathrm{~h}$ & $>5-10 \mathrm{~h}$. & $>10 \mathrm{~h}$. & & \\
\hline & & $67.9 \%$ & $12.3 \%$ & $9.9 \%$ & $9.9 \%$ & & \\
\hline \multirow[t]{17}{*}{$\begin{array}{l}\text { Independent } \\
\text { variables }\end{array}$} & \multirow[t]{2}{*}{$\begin{array}{l}\text { Duration of visit } \\
(\mathrm{N}=145)\end{array}$} & $<0.5 \mathrm{~h}$ & 0.5-1 h. & $>1-2 \mathrm{~h}$ & $>2-3 \mathrm{~h}$ & $>3-4 \mathrm{~h}$ & $>4 \mathrm{~h}$. \\
\hline & & $34.5 \%$ & $2.1 \%$ & $24.8 \%$ & $17.9 \%$ & $14.5 \%$ & $6.2 \%$ \\
\hline & \multicolumn{7}{|l|}{ Reason for visit } \\
\hline & \multirow[t]{2}{*}{ Barbequing $(\mathrm{N}=146)$} & no & yes & & & & \\
\hline & & $78.8 \%$ & $21.2 \%$ & & & & \\
\hline & \multirow[t]{2}{*}{ Transit $(\mathrm{N}=145)$} & no & yes & & & & \\
\hline & & $84.8 \%$ & $15.2 \%$ & & & & \\
\hline & \multicolumn{7}{|l|}{ Statements } \\
\hline & \multirow[t]{2}{*}{$\begin{array}{l}\text { The park is clean } \\
(\mathrm{N}=146)\end{array}$} & $\begin{array}{l}\text { I totally } \\
\text { disagree }\end{array}$ & I disagree & I agree & I fully agree & & \\
\hline & & $13.7 \%$ & $37.0 \%$ & $40.4 \%$ & $8.9 \%$ & & \\
\hline & \multirow[t]{2}{*}{ I feel safe $(\mathrm{N}=146)$} & $\begin{array}{l}\text { I totally } \\
\text { disagree }\end{array}$ & I disagree & I agree & I fully agree & & \\
\hline & & $9.2 \%$ & $24.6 \%$ & $33.1 \%$ & $33.1 \%$ & & \\
\hline & \multicolumn{7}{|l|}{ Improvement } \\
\hline & \multirow[t]{2}{*}{ Security (N=148) } & no & yes & & & & \\
\hline & & $64.2 \%$ & $35.8 \%$ & & & & \\
\hline & \multirow[t]{2}{*}{ Gender $(\mathrm{N}=148)$} & female & male & & & & \\
\hline & & $52.7 \%$ & $47.3 \%$ & & & & \\
\hline
\end{tabular}

WTPgen = general willingness to pay, WTPabs $=$ absolute willingness to pay, WTWgen $=$ general willingness to work, WTWabs $=$ absolute willingness to work

curity might increase, and respondents might even be willing to pay a higher amount. It seems that a certain degree of security is a basic requirement that should be provided by park management to increase users' willingness to support other improvements. The desire for better security in the park is not supported by high willingness to pay values. Respondents favouring other improvement categories were willing to pay more, while the share of respondents already feeling safe and willing to pay was up to ten percentage points higher than the average and up to twenty percentage points higher than the average in the willingness to pay intervals greater than EUR 5. Regarding willingness to work it is significant that respondents who perceive Westpark as being clean are more eager to work than others. This could either mean that cleanliness is a relevant factor for their personal sense of wellbeing in the park or that they do not see litter beeing an issue in the park. Another possibility is that a clean environment may increase their willingness to work to support other improvements.

The sample shows that the unbalanced distribution of respondents among the age groups of below and above fifty years of age in a Mann-Whitney $U$ test (see Weinberg/ Abramowitz 2008) has no significant influence on willingness to pay and willingness to work. With regard to gender, generally, men seem to be slightly more supportive of park improvements than women, as the correlation values for gender show a very low positive relation to general willingness to pay, absolute willingness to pay and general willingness to work (see Table 4). The difference between women and men is also proven by the Mann-Whitney $\mathrm{U}$ test. It is possible that this relates to security problems in the park, as women may not feel safe enough to support improvements. As most respondents live in the postcode area where Westpark is located, respondents' origin is understandably not relevant for explaining their willingness to pay and willingness to work according to the Mann-Whitney $U$ test. Still, with regard to age and origin, the sample is representative for visitors to Westpark.

The analysis of determinants could be further refined by executing regression analyses. These are very complex and difficult to interpret and are therefore only of limited suitability for planning. Still, understanding why respondents 
Table 3 Proportion of significant independent variables on dependent variables

\begin{tabular}{|c|c|c|c|c|c|c|c|c|c|c|}
\hline & & \multicolumn{2}{|c|}{ WTPgen $(\mathrm{N}=135)$} & \multicolumn{2}{|c|}{ WTPabs $(\mathrm{N}=135)$} & \multirow[b]{2}{*}{$\begin{array}{l}>5-15 € \\
(\%)\end{array}$} & \multirow[b]{2}{*}{$\begin{array}{l}>15-30 € \\
(\%)\end{array}$} & \multirow[b]{2}{*}{$\begin{array}{l}>30 € \\
(\%)\end{array}$} & \multicolumn{2}{|c|}{ WTWgen $(\mathrm{N}=81)$} \\
\hline & & no $(\%)$ & $\begin{array}{l}\text { yes } \\
(\%)\end{array}$ & $\begin{array}{l}0 € \\
(\%)\end{array}$ & $\begin{array}{l}>0-5 € \\
(\%)\end{array}$ & & & & no $(\%)$ & yes $(\%)$ \\
\hline \multirow{6}{*}{$\begin{array}{l}\text { Duration } \\
\text { of visit }\end{array}$} & $<0.5 \mathrm{~h}$ & 42.5 & 25.9 & 42.5 & 41.7 & 21.4 & 23.5 & 18.2 & 46.3 & 34.6 \\
\hline & $0.5-1 \mathrm{~h}$. & 3.8 & 0 & 3.8 & 0 & 0 & 0 & 0 & 1.9 & 7.7 \\
\hline & $>1-2 \mathrm{~h}$ & 25.0 & 18.5 & 25.0 & 8.3 & 21.4 & 11.8 & 36.4 & 29.6 & 15.4 \\
\hline & $>2-3 \mathrm{~h}$ & 15.0 & 22.2 & 15.0 & 8.3 & 14.3 & 47.1 & 9.1 & 9.3 & 26.9 \\
\hline & $>3-4 \mathrm{~h}$ & 12.5 & 18.5 & 12.5 & 16.7 & 35.7 & 5.9 & 18.2 & 11.1 & 15.4 \\
\hline & $>4 \mathrm{~h}$ & 1.2 & 14.8 & 1.2 & 25.0 & 7.1 & 11.8 & 18.2 & 1.9 & 0 \\
\hline \multirow[t]{2}{*}{ Barbequing } & no & 84.8 & 70.4 & 84.8 & 75.0 & 50.0 & 70.6 & 90.9 & 87.0 & 80.0 \\
\hline & yes & 15.2 & 29.6 & 15.2 & 25.0 & 50.0 & 29.4 & 9.1 & 13.0 & 20.0 \\
\hline \multirow[t]{2}{*}{ Transit } & no & 80.8 & 94.4 & 80.8 & 75.0 & 100 & 100 & 100 & 79.2 & 84.0 \\
\hline & yes & 18.2 & 5.6 & 19.2 & 25.0 & 0 & 0 & 0 & 20.8 & 16.0 \\
\hline \multirow[t]{4}{*}{$\begin{array}{l}\text { Park is } \\
\text { clean }\end{array}$} & $\begin{array}{l}\text { I totally } \\
\text { disagree }\end{array}$ & 15.0 & 13.2 & 15.0 & 33.3 & 15.4 & 5.9 & 0 & 18.5 & 7.7 \\
\hline & I disagree & 40.0 & 32.1 & 40.0 & 41.7 & 23.1 & 29.4 & 36.4 & 46.3 & 26.9 \\
\hline & I agree & 40.0 & 43.4 & 40.0 & 8.3 & 46.2 & 52.9 & 63.6 & 27.8 & 65.4 \\
\hline & $\begin{array}{l}\text { I fully } \\
\text { agree }\end{array}$ & 5.0 & 11.3 & 5.0 & 16.7 & 15.4 & 11.8 & 0 & 7.4 & 0 \\
\hline \multirow[t]{4}{*}{ I feel safe } & $\begin{array}{l}\text { I totally } \\
\text { disagree }\end{array}$ & 11.5 & 7.7 & 11.5 & 18.2 & 0 & 5.9 & 9.1 & 13.5 & 7.7 \\
\hline & I disagree & 28.2 & 19.2 & 28.2 & 27.3 & 23.1 & 0 & 36.4 & 30.8 & 23.1 \\
\hline & I agree & 37.2 & 28.8 & 37.2 & 18.2 & 30.8 & 41.2 & 18.2 & 36.5 & 38.5 \\
\hline & $\begin{array}{l}\text { I fully } \\
\text { agree }\end{array}$ & 23.1 & 44.2 & 23.1 & 36.4 & 46.2 & 52.9 & 36.4 & 19.2 & 30.8 \\
\hline \multirow[t]{2}{*}{ Security } & no & 48.1 & 79.6 & 48.1 & 58.3 & 78.6 & 94.1 & 81.8 & 45.5 & 53.8 \\
\hline & yes & 51.9 & 20.4 & 51.9 & 41.7 & 21.4 & 5.9 & 18.2 & 54.5 & 46.2 \\
\hline \multirow[t]{2}{*}{ Gender } & female & 61.7 & 42.6 & 61.7 & 50.0 & 35.7 & 41.2 & 45.5 & 69.1 & 46.2 \\
\hline & male & 38.8 & 57.4 & 38.3 & 50.0 & 64.3 & 58.8 & 54.5 & 30.9 & 53.8 \\
\hline
\end{tabular}

WTPgen = general willingness to pay, WTPabs $=$ absolute willingness to pay, WTWgen $=$ general willingness to work

are willing to pay and willing to work, and to what extent, could assist the park management in targeting certain aspects of the park (e.g. security) that influence park users' satisfaction.

\section{Implication of results for the management of city parks}

In the context of these results, we aim to show that a contingent valuation approach allows peoples' preferences to be identified and indicates the reasons for these preferences - which can help support tailor-made planning - and also that contingent valuation results can be made accessible to planners, if assessment is kept practicable and not overly complex. Therefore, economic valuation results should be considered in policymaking for green infrastructure.

\subsection{Extrapolation of users and the fund's budget}

To estimate the total amount of the hypothetical fund that would theoretically be available for reinvestment in Westpark, a user count was carried out following a similar approach to that used by Matz (2006). The user count was based on a random sample of visitors entering Westpark via its seven entrances. At every entrance, adults were counted for five minutes of each hour between $10 \mathrm{am}$ and $8 \mathrm{pm}$. According to the resulting figures, estimations for an average day were calculated. Next, respondents' reported use frequencies were consulted and translated into quantitative figures for monthly visits to extrapolate the amount of individual visitors per month and year. To counteract overestimation, we set the amount of people only crossing Westpark to $25 \%$, instead of the surveyed $4 \%$. In this way, we calculated that approximately 27,000 individuals visit Westpark annually. To extrapolate the total willingness to pay and willingness to work per month and year, average WTP and WTW for each use frequency are employed and multiplied with the respective number of individual park 
Table 4 Significant correlations (Spearman's rank correlation coefficient)

\begin{tabular}{|c|c|c|c|c|c|c|c|}
\hline & $\begin{array}{l}\text { Length of } \\
\text { stay }\end{array}$ & $\begin{array}{l}\text { Reason: Bar- } \\
\text { beque }\end{array}$ & $\begin{array}{l}\text { Reason: Tran- } \\
\text { sit }\end{array}$ & $\begin{array}{l}\text { Statement: } \\
\text { Westpark is } \\
\text { clean }\end{array}$ & $\begin{array}{l}\text { Statement: } \\
\text { I feel safe }\end{array}$ & $\begin{array}{l}\text { Improvement: } \\
\text { Security }\end{array}$ & Gender: male \\
\hline WTPgen & $0.277^{* *}$ & $0.174^{*}$ & $-0.196^{*}$ & & $0.201^{*}$ & $-0.316^{* *}$ & $0.188^{*}$ \\
\hline WTPabs & $0.273^{* *}$ & & $-0.229^{* *}$ & & $0.202^{*}$ & $-0.338^{* *}$ & $0.183^{*}$ \\
\hline WTWgen & & & & $0.233^{*}$ & & & $0.220^{*}$ \\
\hline WTWabs & & & & & & & \\
\hline
\end{tabular}

WTPgen = general willingness to pay, WTPabs = absolute willingness to pay, WTWgen = general willingness to work, WTWabs $=$ absolute willingness to work

** correlation is significant at the 0.01 level (2-tailed)

*correlation is significant at the 0.05 level (2-tailed)

visitors. According to this procedure, total monthly and annual willingness to pay would be EUR 144,000 and EUR 245,000 , respectively. Working hours per month and per year to support park management would be 13,000 and 16,000 , respectively. To sum up the WTP and WTW values, we converted working hours into euro values by means of an hourly wage. This may, of course, bias the result as the choice of an hourly wage strongly influences the total value. However, for practical reasons we choose to refer to the political debates regarding "EUR 1 Jobs" and the current minimum wage of EUR 8.50 in Germany. This reflects the widespread discussion of Germany's low-pay sector. Taking both values into account, we arrive at EUR 16,000 or EUR 136,000. For this calculation, we decided to use the average of EUR 76,000. Accordingly, the total annual willingness to pay and willingness to work of all park users, and thus the budget of the fund for improvement measures and proposals, would theoretically be EUR 321,000.

\subsection{Suggestions for park management actions}

Based on respondents' preferences regarding the improvement categories, as well as their proposals and the relations between willingness to pay and willingness to work identified in the analysis, we discuss and suggest the possible implementation of certain park management actions within the improvement categories. Most of these actions also emerged as issues in the expert interviews and meetings of the Westpark working group and were therefore investigated in the pilot survey and then further specified in the final survey. Costs were derived from German standard costs of real time investments (BKI 2012). This approach is taken to "translate" the social value of park improvements, revealed by the WTP and WTW values, into values that are more comprehensible to practitioners.

As most interviewees put an emphasis on improvements in design and furniture, many proposals should relate to this category. EUR 160,000 would be needed to refurbish the two playgrounds in Westpark (see Table 5). Although this is a large amount, a city park in such a central location should house attractive playgrounds to serve families with children, one of its main user groups. Further, we suggest the construction of ten new park benches, mainly close to the retirement centre and the playgrounds, which would help meet the needs of elderly people and families. Other proposals, such as public toilets and a pond, should not be implemented due to the high costs of realization and maintenance and low support amongst survey respondents.

To improve cleanliness in Westpark, more and bigger waste bins should be placed on and around the barbeque area to enable users to dispose of their waste easily and quickly. The benefit, compared to the costs of EUR 9,000, should be enormous. Furthermore, a job creation program could be developed, employing workers to collect waste for low wages, thus addressing cleanliness concerns and providing job opportunities. This suggestion may conflict with the fact that respondents willing to work tend not to prefer improvements in cleanliness. Still, this job creation program could provide a practical solution to littered vegetation and lawns.

Although few respondents are willing to pay for improvements related to safety and security, this topic seems to be highly relevant as drug use and dealing were often reported in the park. Increasing the level of security, and thus the personal safety of park users, appears to be essential to improving users' sense of wellbeing in Westpark. Of the proposals cited earlier, more lights might improve safety, as dark areas could be avoided and useable hours of the park would be extended. The 15 lights proposed, which would cost more than EUR 30,000, should be robust to protect them from vandalism. More security personnel may not be an efficient solution, as their power against drug use and dealing is limited (this is mainly the responsibility of the police). Given the widespread privacy concerns amongst the German public, closed-circuit television could potentially alienate people, be targeted by vandalism and diminish the character of the park. Horticultural maintenance is not a priority concern among park users and is therefore not considered. 
Table 5 Costs of suggested proposals (own calculations, based on BKI 2012 and estimations from personal communications)

\begin{tabular}{llll}
\hline $\begin{array}{l}\text { Improvement } \\
\text { area }\end{array}$ & Proposal & Amount & $\begin{array}{l}\text { Costs in } \\
\mathbf{\epsilon}\end{array}$ \\
$\begin{array}{l}\text { Design and } \\
\text { furniture }\end{array}$ & $\begin{array}{l}\text { Playground refurbish- } \\
\text { ment }\end{array}$ & 2 & 160,000 \\
& $\begin{array}{l}\text { Park benches } \\
\text { Cleanliness }\end{array}$ & 10 & 6,500 \\
& Waste bins & 15 & 9,000 \\
& $\begin{array}{l}\text { Cleaning staff through } \\
\text { job creation scheme }\end{array}$ & & 76,000 \\
Security & Lights & 15 & $30,000 *$ \\
Maintenance & & & $(130,000)$ \\
Total & & & $\mathbf{2 8 1 , 5 0 0}$ \\
$*$ without installation & & \\
\hline
\end{tabular}

We suggest that EUR 281,500 out of the EUR 321,000 hypothetical budget should be used for improvements. However, the installation costs of the lights are not included in this figure and would certainly require most of the remaining amount. Although the suggestions in this section are based on users' preferences, revealed by their willingness to pay and willingness to work and are hypothetical in nature, they highlight the high social values park visitors attach to potential improvements, identify possible reasons for these values, and help to indicate where to focus park management actions. Through park improvements, the general attractiveness of Westpark could be increased, which could lead to longer park visits, fewer respondents using the park only for transit, better safety and security, and thus higher overall satisfaction.

\subsection{Limitations of the study}

However, willingness to pay values derived from contingent valuation studies tend to overestimate real willingness to pay. The same might be true for willingness to work. Therefore, the total hypothetical budget could be smaller than estimated. Additionally, the sample size is not statistically representative, neither of Dortmund nor of the district. The district where Westpark is located has a population of about 52,000, the whole city of Dortmund of about 580,000 (Stadt Dortmund 2009: 22). The low sample size may also affect the extrapolation of users and thus the estimation of the fund's budget. Another issue is selection biases, which can be related to the random selection of both survey participants and counted visitors. Still, according to results from the Mann-Whitney U test, the survey seems to be representative for Westpark users and fits well into the socioeconomic context of the district. Primarily, we would like to underscore the importance of quantitative and qualitative information obtained through contingent valuation for park management and policy.
Willingness to work, in particular, might well have a high potential for green infrastructure management in the future, as it highlights a certain readiness in society to tackle problems and to work together for a common goal. In comparison to willingness to pay, willingness to work seems to be easier to implement in reality as people might be more eager to work physically than to pay money. Willingness to pay should be seen more in the light of providing strategic arguments for decision makers to invest in green spaces and to showcase the high significance of green infrastructure assets such as parks for society. Thus, willingness to pay and willingness to work surveys can function as practical and understandable tools in an integrated, user-orientated planning approach to green infrastructure planning and management.

\section{Conclusion}

The aim of this paper is to pinpoint the opportunities a contingent valuation survey provides for green infrastructure planning, using the case study of an urban park. This aim was accomplished by applying the contingent valuation method to Westpark in Dortmund, which is centrally located in a densely populated district and suffers from diverse problems that reveal a need for action in park management. Therefore, users of the park were surveyed, asked to choose their favourites from four improvement categories, and asked to state willingness to pay or willingness to work. The results underscore the serious need for action within the improvement categories, with an emphasis on design and furniture improvements. Further, the results provide links between certain variables and willingness to pay and willingness to work, which reveal respondents' length of stay (and thus intensive use of the park, as opposed to merely commuting through it), safety, and security as significant factors.

The present approach clearly shows that identifying and understanding users' preferences is helpful in guiding and justifying park management, especially when public finances are limited. Furthermore, by identifying the determinants of respondents' willingness to pay and willingness to work, important information related to preferences, attitudes, and use characteristics can be derived for the future planning of city parks. To make contingent valuation accessible to practitioners and thus comprehensible for policy and decision making, we set the budget of the hypothetical fund as equivalent to the social value of park improvements in relation to the costs of the most favoured improvement categories and proposals. Thus, it becomes clear that the hypothetical budget would be sufficient to fund those proposals that are important to users, such as new playgrounds, more benches, waste bins and lights. 
These considerations are just theoretical, but they could potentially introduce contingent valuation to planning and decision making and could offer practitioners a new views of green infrastructure planning and management. Therefore, the present study was made available to the body responsible for landscape and green space planning in Dortmund. There has been no evaluation of the study's impact on the management of Westpark, but to date most of the proposed improvements such as special waste bins for the barbecuing area, more lights along the main corridor, new playgrounds and increased shrub cutting in summer times to limit hide-out possibilities have been implemented, some of them with the participation of local residents and users. Another conclusion may be that the introduction of an entrance fee for Westpark, and for parks in general, might provide a solution to current problems of park management. In Germany, it is not easy to introduce entrance fees in a politically acceptable way. In the case of Westpark, entrance fees would not be appropriate due to its character as a district park, the risk of social resistance and the cultural expectation in Germany that public authorities have the responsibility to provide public green infrastructure. There is a park in Dortmund that charges an admission fee, but this park has more amenities of regional significance to offer than Westpark.

There is no doubt that public green infrastructure such as city parks will, due to its character, always require public funding (Willis 2003). Contingent valuation may provide an effective solution by directing financial resources for green infrastructure planning and by incorporating users' preferences into decision making.

\section{References}

Ahmed, S.U.; Gotoh, K. (2007): Estimation of the willingness to pay for preserving public parks in Nagasaki City by using contingent valuation. In: Reports of the Faculty of Engineering, Nagasaki University 37, 68, 53-60.

Amundsen, O. M.; Allen, W.; Hoellen, K. (2009): Green Infrastructure Planning: Recent Advances and Applications. http://www. carolinamountain.org/sites/default/files/files/Nature\%20and\%20 Commerce/4\%20PASMemoMay-June09.pdf (October 12, 2016).

Arrow, K.; Solow, R.; Portney, P.R.; Learner, E.E.; Radner, R.; Schuman, H. (1993): Report of the NOAA Panel on Contingent Valuation. Washington, DC.

Bateman, I.J.; Landford, I.H.; Willis, K.G.; Turner, R.K.; Garrod, G.D. (1993): The Impacts of Changing Willingness to Pay Question Format in Contingent Valuation Studies: An Analysis of Openended, iterative Bidding and Dichotomous Choice Formats. Norwich. = CSERGE Working paper GEC 1993-05

Bateman, I.J.; Harwood, A.R.; Mace, G.M.; Watson, R.T.; Abson, D.J.; Andrews, B.; Binner, A.; Crowe, A.; Day, B.H.; Dugdale, S.; Fezzi, C.; Foden, J.; Hadley, D.; Haines-Young, R.; Hulme, M.; Kontoleon, A.; Lovett, A.A.; Munday, P.; Pascual, U.; Paterson, J.; Perino, G.; Sen, A.; Siriwardena, G.; van Soest, D.; Termansen, M. (2013): Bringing Ecosystem Services into Economic Decision-Making: Land Use in the United Kingdom. In: Science 341, 6141, 45-50.
BKI - Baukosteninformationszentrum Deutscher Architektenkammern (2012): Objektdaten Freianlagen. Kosten abgerechneter Objekte mit statistischen Kostenkennwerten. Stuttgart.

Bühl, A. (2010): PASW 18. Einführung in die moderne Datenanalyse. München.

Carson, R.T. (2012): Contingent valuation: A practical alternative when prices aren't available. In: Journal of Economic Perspectives $26,4,27-42$.

Carson, R.T.; Flores, N.E.; Meade, N.F. (2001): Contingent Valuation: Controversies and Evidence. In: Environmental and Resource Economics 19, 2, 173-210.

Chiesura, A. (2004): The role of urban parks for the sustainable city. In: Landscape and Urban Planning 68, 1, 129-138.

Christie, M. (1999): An Assessment of the Economic Effectiveness of Recreation Policy using Contingent Valuation. In: Journal of Environmental Planning and Management 42, 4, 547-564.

Costa, C.S. (2007): Ökonomische Argumente für eine Grünflächenentwicklung. In: Stadt und Grün 56, 2, 13-19.

Del Saz Salazar, S.; Menendez, L.G. (2007): Estimating the non-market benefits of an urban park: Does proximity matter? In: Land Use Policy 24, 1, 296-305.

Elsasser, P.; Meyerhoff, J.; Montagné, C.; Stenger, A. (2009): A bibliography and database on forest benefit valuation studies from Austria, France, Germany, and Switzerland - A possible base for a concerted European approach. In: Journal of Forest Economics $15,1-2,93-107$.

Europäische Kommission (2013): Grüne Infrastruktur (GI) Aufwertung des europäischen Naturkapitals. http://eur-lex. europa.eu/resource.html?uri=cellar:d41348f2-01d5-4abe-b8174c73e6f1b2df.0012.04/DOC_1\&format=PDF (October 12, 2016).

Freeman III., A.M.; Herriges, J.A.; Kling, C.L. (2014): The Measurement of Environmental and Resource Values. Theory and Methods. Hoboken.

Gälzer, R. (2001): Grünplanung für Städte. Planung, Entwurf, Bau und Erhaltung. Stuttgart.

Gronemann, S.; Hampicke, U. (1997): Die Monetarisierung der Natur. Möglichkeiten, Grenzen und Methoden. In: Weise, P. (ed.): Nachhaltigkeit in der ökonomischen Theorie. Frankfurt am Main, 164207. = Jahrbuch Ökonomie und Gesellschaft 14.

Gruehn, D. (2013): Germany Goes Green - Innovations towards a Sustainable Regional Development. In: World Technopolis Review 1, $4,230-239$.

Grunert, H. (2001): Grün Macht Geld - Macht Geld Grün. Die ökonomische Bedeutung des Stadtgrüns. In: Stadt und Grün $50,8,539-544$.

Haab, T.C.; Interis, M.G.; Petrolia, D.R.; Whitehead, J.C. (2013): From Hopeless to Curious? Thoughts on Hausman's "Dubious to Hopeless" Critique of Contingent Valuation. In: Applied Economic Perspectives and Policy 35, 4, 593-612.

Hausman, J. (2012): Contingent Valuation: From Dubious to Hopeless. In: Journal of Economic Perspectives 26, 4, 43-56.

James, P.; Tzoulas, K.; Adams, M.D.; Barber, A.; Box, J.; Breuste, J.; Elmqvist, T.; Frith, M.; Gordon, C.; Greening, K.L.; Handley, J.; Haworth, S.; Kazmierczak, A.E.; Johnston, M.; Korpela, K.; Moretti, M.; Niemelä, J.; Pauleit, S.; Roe, M.H.; Sadler, J.P.; Ward Thompson, C. (2009): Towards an integrated understanding of green space in the European built environment. In: Urban Forestry and Urban Greening 8, 2, 65-75.

Jilkova, J.; Holländer, R.; Kochmann, L.; Slavik, J.; Slavikova, L. (2010): Economic Valuation of Environmental Resources and its Use in Local Policy Decision-Making: A Comparative CzechGerman Border Study. In: Journal of Comparative Policy Analysis $12,3,299-309$.

Johnston, R.J. (2006): Is hypothetical bias universal? Validating contingent valuation responses using a binding public referendum. In: Environmental Economics and Management 52, 1, 469-481. 
Klaphake, A. (2003): Mehr Ökonomie für den Freiraum! Konzeptionelle Grundlagen und empirische Ergebnisse der Ökonomie städtischer Freiräume. In: Stadt und Grün 52, 10, 7-13.

Klaphake, A.; Meyerhoff, J. (2003): Der ökonomische Wert städtischer Freiräume. In: Raumforschung und Raumordnung 61, 1-2, 107117.

Knetsch, J.L. (2010): Values of gains and losses: Reference states and choice of measure. In: Environmental and Resource Economics $46,2,179-188$

Matz, K. (2006): Was ist ein Stadtpark wert? Ökonomische Bewertung des Görlitzer Parks in Berlin mit einer Zahlungsbereitschaftsanalyse. Berlin. = Landschaftsentwicklung und Umweltforschung 128.

McConnell, V.; Walls, M. (2005): The Value of Open Space: Evidence from Studies of Nonmarket Benefits. Washington, DC.

Meyerhoff, J. (2004): Der Einfluss von Einstellungen auf die Zahlungsbereitschaft für Veränderungen in Natur und Landschaft. Ergebnisse aus zwei Kontingenten Bewertungen zum Wattenmeer und zur Elbe. Frankfurt am Main.

Milchert, J. (2005): Mit Grün Geld verdienen. In: Stadt und Grün 54, $1,11-15$.

Mitchell, R.C.; Carson, R.T. (1989): Using Surveys to Value Public Goods: The Contingent Valuation Method. Washington, D.C.

Neumeyer, H.-P.; Kieslich, W.; Liesen, M. (2004): StadtgrünPlan. Stadtbezirk Innenstadt-West. Erstellt im Auftrag der Stadt Dortmund, Regiebetrieb Stadtgrün. Dortmund.

Pearce, D.W.; Atkinson, G.; Mourato, S. (2006): Cost-Benefit Analysis of the Environment. Recent Developments. Paris.

Schröder, T. (2000): Der Park lebt nicht vom Staat allein. In: Topos 19, 68-74.
Slootweg, R.; van Beukering, P.J.H. (2008): Valuation of Ecosystem Services and Strategic Environmental Assessment: Lessons from Influential Cases. Report of the Netherlands Commission for Environmental Assessment. Utrecht.

Stadt Dortmund (2006): Parks und Gärten in Dortmund. Dortmund.

Stadt Dortmund (2009): Statistisches Jahrbuch. Dortmunder Statistik 2009. Dortmund.

Stewart, S.; Kahn, J.R. (2009): An introduction to choice modeling for non-market valuation. In: Alberini, A.; Kahn, J.R. (eds.): Handbook on Contingent Valuation. Cheltenham/Northampton, 153176.

TEEB - The Economics of Ecosystems and Biodiversity (2010): The Ecological and Economic Foundations. London.

Venkatachalam, L. (2004): The contingent valuation method: a review. In: Environmental Impact Assessment Review 24, 1, 89-124.

Weinberg, S.L.; Abramowitz, S.K. (2008): Statistics using SPSS. An Integrative Approach. Cambridge.

Whitehead, J.C. (2006): A practitioner's primer on the contingent valuation method. In: Alberini, A.; Kahn, J.R. (eds.): Handbook on Contingent Valuation. Cheltenham/Northhampton, 66-91.

Wilker, J. (2010): GrünAnlage - Was ist uns Stadtgrün wert? Ökonomische Bewertung des Westparks in Dortmund. Diplomarbeit, Technische Universität Dortmund.

Wilker, J.; Rusche, K. (2014): Economic valuation as a tool to support decision-making in strategic green infrastructure planning. In: Local Environment 19, 6, 702-713.

Wilker, J.; Rusche, K.; Benning, A.; MacDonald, M.A.; Blaen, P. (2016): Applying ecosystem benefit valuation to inform quarry restoration planning. In: Ecosystem Services 20, 44-55.

Willis, K.G. (2003): Pricing Public Parks. In: Journal of Environmental Planning and Management 46, 1, 3-17. 